\title{
APLIKASI REMOTE KONTROL CPU/LAPTOP JARAK JAUH DENGAN MEDIA SERIAL HANDPHONE DENGAN MIKROKONTROLER
}

\author{
Rozali Toyib ${ }^{1}$, Juni Hidayatullah ${ }^{2}$ \\ 1,2 Informatika, Fakultas Teknik Universitas Muhammadiyah Bengkulu \\ Jl. Bali Po. Box, 118 Kota Bengkulu 38119 INDONESIA \\ (Telp 0736-22765 Fak. 0736-26161 \\ ${ }^{1}$ rozalitoyib@gmail.com \\ ${ }^{2}$ junihadi@yahoo.com
}

\begin{abstract}
Abstrak: Teknologi remote control telah banyak dikembangkan dengan memanfaatkan berbagai media transmisi. Mikrokontrolerbekerja dalam bahasa mesin sedangkan manusia sulit untuk mengerti bahasa mesin. Software yang sering digunakan yaitu C, Basic, atau Assembler, selanjutnya dengan bantuan Compiler program akan diterjemahkan dalam bahasa mesin. Mikrokontroler yaitu tipe AVR salah satunya adalah Atmega16. Dari aspek Androidmerupakan system operasi untukhandphone. System operasi ini menyediakan platform terbuka bagi para pengembang untuk menciptakan aplikasi baru dari CodeVisionAVR dan Microsoft Visual Studio. Dilihat dari aspek pengendalian robot, bluetooth merupakan teknologi komunikasi tanpa kabel yang digunakan untuk transfer data antara robot dan aplikasi blueterm yang bisa digunakan pada sistem operasi untuk handphone.
\end{abstract}

Kata Kunci: Remote Control, Compiler, Mikrokontroler, Hanphone, Bluetooth

\begin{abstract}
Remote control technology has been developed by utilizing a variety of transmission media. microcontroller work in the machine while human language is difficult to understand the language of the machine. Software is often used, namely C, Basic, or Assembler, Compiler further with the help of the program will be translated into machine language. namely type AVR microcontroller which is ATmega16 one. From the aspect of Android is an operating system for mobile phones. The operating system provides an open platform for developers to create new applications from CodeVision AVR and Microsoft Visual Studio. Viewed from the aspect of robot control, Bluetooth is a wireless communication technology that is used to transfer data between the robot and blueterm applications that can be used in the operating system for mobile phones.
\end{abstract}

Keyword: Remote Control, Compiler, Microcontroler, Hanphone, Bluetooth.

\section{PENDAhUluan}

Teknologi remote control telah banyak dikembangkan dengan memanfaatkan berbagai media transmisi. Beberapa diantaranya adalah remote controldengan memanfaatkan media inframerah, bluetooth, gelombang radio, internet dan saluran telepon baik pada bermacam macam peralatan elektronik, kendaraan dan lain-lain. Sistem remote control melalui saluran telepon memiliki keunggulan dalam hal jarak jangkauan dan kepraktisan dibanding media lainnya.

Perangkat pengembangan suatu sistem mikrokontroleradalah sangat penting untuk melakukan ekperimen dengan mikrokontroleryang dipilih, mikrokontroler bekerja dalam bahasa mesin sedangkan manusia sulit untuk mengerti bahasa mesin. Software yang sering digunakan yaitu C, Basic, atau Assembler, selanjutnya dengan bantuan Compiler program akan diterjemahkan dalam bahasa mesin.

CodeVision AVR C Compiler adalah software yang digunakan untuk membuat program 
mikrokontroler AVR dalam bahasa C. Program tersebut kemudian diterjemahkan oleh CodeVision AVR C menjadi kode heksadesimal yang akan di download ke dalam chip mikrokontroler AVR. CodeVision AVR dapat mengimplementasi hampir semua instruksi bahasa C yang sesuai dengan arsitektur AVR, bahkan terdapat keunggulan spesifik dari AVR. Hasil kompilasi objek CodeVision AVR bisa digunakan sebagai source debug dengan AVR Studio debugger dari ATMEL.

Aplikasi kontrol CPU, dilihat dari aspek mikrokontroler yaitu tipe AVR salah satunya adalah Atmega16. Dari aspek Android merupakan sistem operasi untukhandphone. Sistem operasi ini menyediakan platform terbuka bagi para pengembang untuk menciptakan aplikasi baru dari CodeVision AVR dan Microsoft Visual Studio. Dilihat dari aspek pengendalian robot, bluetooth merupakan teknologi komunikasi tanpa kabel yang digunakan untuk transfer data antara robot dan aplikasi blueterm yang bisa digunakan pada sistem operasi untuk handphone.

Dari latar belakang di atas, maka peneliti tertarik untuk membangun sebuah Aplikasi Remot Kontrol CPU/Laptop Jarak Jauh Dengan Media Serial Handphone Dengan Mikrokontroler.

\section{LANDASAN TEORI}

\section{A. Android}

Android adalah sebuah toolkit software yang baru untuk perangkat bergerak yang dibuat oleh Google dan Open Handset Alliance. Dalam beberapa tahun, Android diharapkan dapat ditemukan dalam jutaan handphone dan berbagai perangkat bergerak, membuat Android menjadi platform utama untuk pengembang aplikasi.

Sudah ada banyak platformmobile di pasar saat ini, termasuk Symbian, iPhone, Windows
Mobile, BlackBerry, Java Mobile Edition, Linux Mobile (LiMo), dan banyak lagi. Meskipun beberapa fitur-fiturnya telah muncul s ebelumnya, Android adalah platform pertama yang menggabungkan beberapa hal berikut :

1. Android merupakan sebuah platform yang berbasis Linux dan open source. Pembuat handset menyukai hal ini karena mereka dapat menggunakan dan menyesuaikan platform tanpa membayar royalti.

2. Sebuah arsitektur berbasis komponen. Bagian dari aplikasi Android dapat digunakan sebagai bahan lain yang bahkan tidak dibayangkan oleh developer. Kita dapat menggantikan built-in komponen aplikasi Android dengan versi pengembangan sendiri.

3. Banyak built-in service yang tidak biasa. Servis berdasarkan lokasi menggunakan GPS atau cell tower triangulation yang membuat pengalaman pemakai terjadi bergantung lokasi.

Android menyediakan jalur yang segar dalam aplikasi mobile berinteraksi dengan pemakai, bersama dengan teknik yang mendasar untuk membuatnya mungkin. Tetapi hal yang paling menarik dalam Android adalah kita dapat menulis sendiri aplikasinya [1].

Android adalah sistem operasi untuk mobile device yang awalnya dikembangkan oleh Android Inc.Perusahaan ini kemudian dibeli oleh Google pada tahun 2005. Android dibuat berdasarkan kernel Linux yang dimodifikasi. Aplikasi Android ditulis dengan bahasa Java, menggunakan Java Core Libraries.

\section{B. Bluetooth}

Bluetoot hadalah Sebuah teknologi wireless yang mampu menyediakan layanan komunikasi data dan suara dengan jarak jangkauan yang terbatas. Bluetooth adalah sebuah teknologi 
komunikasi wireless (tanpa kabel) yang beroperasi dalam pita frekuensi $2,4 \mathrm{GHz}$ unlicensed ISM (Industrial, Scientific and Medical) dengan menggunakan sebuah frequency hopping tranceiver yang mampu menyediakan layanan komunikasi data dan suara secara real-time antara host bluetooth dengan jarak jangkauan layanan yang terbatas.

BluetoothV3 keluaran dari DFRobot yang digunakan sebagai perantara komunikasi bluetooth antara microcontroller dengan handphone berbasis Android. Komunikasi bluetooth yang digunakan memiliki karakteristik sebagai berikut :

1. Kekuatan pengiriman sinyal sebesar $4 \mathrm{dBm}$ (maksimum).

2. Menggunakan tipe komunikasi serial dengan jangkauan komunikasi pada lapangan terbuka 10 meter.

3. Bluetooth V3 dapat bekerja dengan baik pada temperature $0^{\circ}$ hingga $70^{\circ} \mathrm{C}$.

4. Supply Power sebesar 5 hingga 12 VDC.

5. Konsumsi arus sebesar $3 \mathrm{~mA}$ hingga $35 \mathrm{~mA}$ (bergantung pada kondisi koneksi dan Baud Rate).

6. Tidak dapat menggunakan kode enkripsi dan sistem security yang lain (misalnya Passkey).

Bluetooth V3 memiliki 2 mode operasi utama yaitu command mode dan data mode. Setiap kali dilakukan power up, bluetooth V3 akan selalu masuk dalam command mode dan siap untuk menerima serial command. Pada command mode ini terdapat beberapa perintah yang dapat dikirim untuk menggunakan berbagai macam fitur yang dimiliki oleh bluetooth V3. Adapun gambar bluetooth V3 dapat dilihat pada gambar dibawah ini.

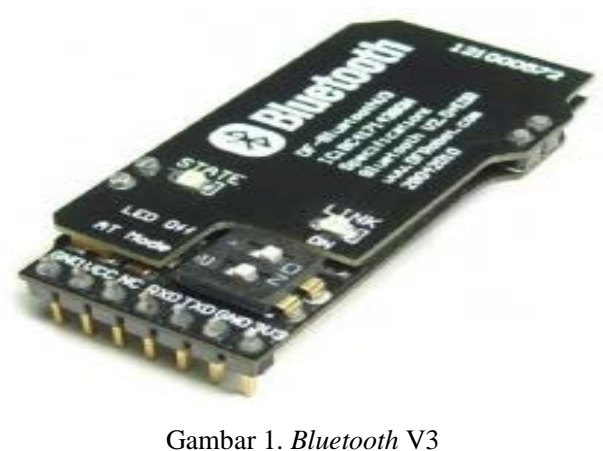

Perintah-perintah itu antara lain adalah : get con $<\mathrm{CR}>$ (notasi $<\mathrm{CR}>$ merupakan 0Ah dan 0Dh) : perintah untuk melihat kondisi connectable dari Bluetooth V3 yang digunakan, get dis $<\mathrm{CR}>$. Perintah untuk melihat kondisi discoverable dari bluetooth V3 yang digunakan untuk mencari bluetooth lain yang masuk dalam jangkauan bluetooth V3 dan dalam keadaan discoverable on, set dis status $<\mathrm{CR}>$. Perintah untuk merubah kondisi discoverable dari bluetooth V3 variabel status diisi on (aktif) atau off (non aktif).

Tabel 1. Konfigurasi Pin Bluetooth V3

\begin{tabular}{|c|c|l|}
\hline Nama Pin & Type Pin & \multicolumn{1}{|c|}{ Keterangan } \\
\hline VSS & $+5 \mathrm{~V}$ & $\begin{array}{l}\text { Mengambil daya dari catu } \\
\text { daya }\end{array}$ \\
\hline GND & GND & $\begin{array}{l}\text { Menghubungkan pada port } \\
\text { D }\end{array}$ \\
\hline RX & TX & USART data output \\
\hline TX & TX & USART data input \\
\hline
\end{tabular}

C. Mikrokontroler Atmega16

Mikrokontrolermerupakan suatu alat elektronika digital yang mempunyai masukan dan keluaran serta kendali dengan program yang bisa ditulis dan dihapus dengan cara khusus, cara kerja mikrokontroler sebenarnya membaca dan menulis data [2].

Mikrokontroler yang biasa digunakan pada boardArduino. Atmega32 merupakan mikrokontroler keluarga AVR 8 bit. Beberapa tipe mikrokontroler yang sama dengan Atmega 8 ini antara lain Atmega8535, Atmega16, Atmega32, 
Atmega 328, yang membedakan antara mikrokontroler antara lain adalah, ukuran memori, banyaknya GPIO (pin input/output), peripherial (USART, timer, counter, dan lain-lain). Dari segi ukuran fisik, Atmega328 memiliki ukuran fisik lebih kecil dibandingkan dengan beberapa mikrokontroler di atasnya.

Namun untuk segi memori dan periperial lainnya Atmega328 tidak kalah dengan yang lainnya karena ukuran memori dan periperial relatif sama dengan Atmega8535, Atmega32, hanya saja jumlah GPIO lebih sedikit dibandingkan mikrokontroler diatasnya. Pin out IC mikrokontroler Atmega16 yang berpackage DIP dapat dilihat pada gambar 2.

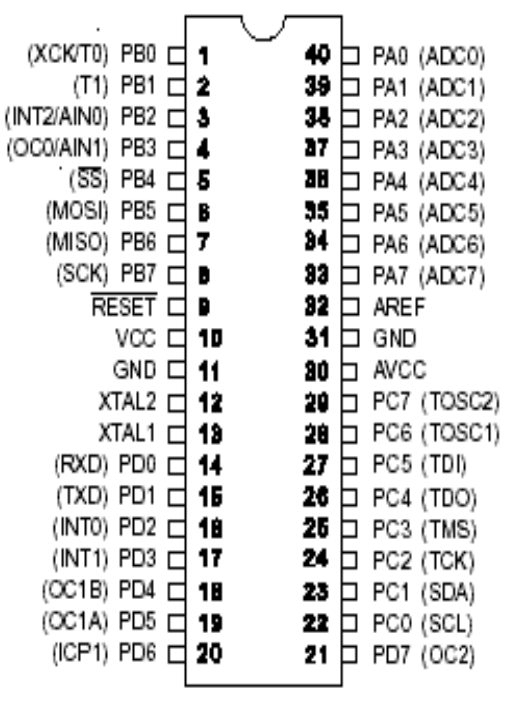

Gambar 2. Pin Mikrokontroler ATMega16

Penjelasan dari masing-masing pin

mikrokontroler Atmega 16 adalah sebagai berikut :

1. VCC meruspakan pin yang berfungsi sebagai pin masukkan catu daya.

2. GND merupakan pin ground yang terhubung pada port $D$.

3. Port A (PA7...PA0) merupakan terminal masukkan analog A/D converter. Port ini juga berfungsi sebagai port I/O 8 bit dua arah (bidirectional), jika A/D converter tidak diaktifkan.

4. Port B (PB7...PB0) merupakan port I/O 8 bit dua arah (bidirectional) dengan resistor pull-up internal. Port B juga dapat berfungsi sebagai terminal khusus yaitu timer/counter, komparator analog, dan SPI.

5. Port C (PC7...PC0) merupakan port I/O 8 bit dua arah (bidirectional) dengan resistor pull-up internal. Port C juga dapat berfungsi sebagai terminal khusus yaitu komparator analog, dan timer oscilator.

6. Port D (PD7...PD0) merupakan port I/O 8 bit dua arah (bidirectional) dengan resistor pull-up internal. Port D juga dapat berfungsi sebagai terminal khusus yaitu komparator analog, interupsi internal, dan komunikasi serial.

7. Reset merupakan pin yang digunakan untuk me-reset mikrokontroler.

8. XTAL1 dan XTAL2 merupakan pin masukkan clock eksternal.

9. AVCC merupakan pin masukkan tegangan untuk ADC.

10. AREF merupakan pin masukkan tegangan referensi ADC.

Atmega16 memiliki 3 buah port utama yaitu port $\mathrm{B}$, port $\mathrm{C}$, dan port $\mathrm{D}$ dengan total pin input/output sebanyak 23 pin. Port tersebut dapat difungsikan sebagai input/output digital atau difungsikan sebagai periperial lainnya :

\section{Port B}

Port B merupakan jalur data 8 bit yang dapat difungsikan sebagai input/output. Selain itu port B juga dapat memiliki fungsi alternatif seperti di bawah ini.

a. ICP1 (PB0), berfungsi sebagai Timer Counter 1 input capturepin 
b. OC1A (PB1), OC1B (PB2) dan OC2 (PB3) dapat difungsikan sebagai keluaran PWM (pulse width modulation).

c. MOSI (PB3), MISO (PB4), SCK (PB5), SS (PB2) merupakan jalur komunikasi SPI.

d. Selain itu pin ini juga berfungsi sebagai jalur pemrograman serial (ISP).

e. TOSC1 (PB6) dan TOSC2 (PB7) dapat difungsikan sebagai sumber clock external untuk timer.

f. XTAL1 (PB6) dan XTAL2 (PB7) merupakan sumber clock utama mikrokontroler.

2. Port $\mathrm{C}$

Port C merupakan jalur data 7 bit yang dapat difungsikan sebagai input/output digital. Fungsi alternatif port $\mathrm{C}$ antara lain sebagai berikut :

a. ADC6 channel (PC0,PC1,PC2,PC3,PC4,PC5) dengan resolusi sebesar 10 bit. ADC dapat kita gunakan untuk mengubah input yang berupa tegangan analog menjadi data digital. I2C (SDA dan SDL) merupakan salah satu fitur yang terdapat pada port C.

b. I2C digunakan untuk komunikasi dengan sensor atau device lain yang memiliki komunikasi data tipe I2C seperti sensor kompas, accelerometer nunchuck.

\section{Port D}

Port D merupakan jalur data 8 bit yang masing-masing pin-nya juga dapat difungsikan sebagai input/output. Sama seperti Port B dan Port C, Port D juga memiliki fungsi alternatif di bawah ini :

a. USART (TXD dan RXD) merupakan jalur data komunikasi serial dengan level sinyal TTL. Pin TXD berfungsi untuk mengirimkan data serial, sedangkan RXD kebalikannya yaitu sebagai pin yang berfungsi untuk menerima data serial.

b. Interrupt (INT0 dan INT1) merupakan pin dengan fungsi khusus sebagai interupsi hardware. Interupsi biasanya digunakan sebagai selaan dari program, misalkan pada saat program berjalan kemudian terjadi interupsi hardware/software maka program utama akan berhenti dan akan menjalankan program interupsi.

c. XCK dapat difungsikan sebagai sumber clock external untuk USART, namun kita juga dapat memanfaatkan clock dari CPU, sehingga tidak perlu membutuhkan external clock.

d. T0 dan T1 berfungsi sebagai masukan counter external untuk timer 1 dan timer 0.

e. AIN0 dan AIN1 keduanya merupakan masukan input untuk analog comparator.

\section{Arsitektur CPU Atmega16}

Fungsi utama CPU adalah memastikan pengeksekusian instruksi dilakukan dengan benar. Oleh karena itu CPU harus dapat mengakses memori, melakukan kalkulasi, mengontrol peripheral, dan menangani interupsi. Ada 32 buah General Purpose Register yang membantu $A L U$ bekerja. Untuk operasi aritmatika dan logika, 
operand berasal dari dua buah general register dan hasil operasi ditulis kembali ke register. Status and Control berfungsi untuk menyimpan instruksi aritmatika yang baru saja dieksekusi.

Informasi ini berguna untuk mengubah alur program saat mengeksekusi operasi kondisional. Instruksi dijemput dari flash memory. Setiap byte flash memory memiliki alamat masing-masing. Alamat instruksi yang akan dieksekusi senantiasa disimpan program counter. Ketika terjadi interupsi atau pemanggilan rutin biasa, alamat di program counter disimpan terlebih dahulu distack. Alamat interupsi atau rutin kemudian ditulis ke program counter, instruksi kemudian dijemput dan dieksekusi. Ketika CPU telah selesai mengeksekusi rutin interupsi atau rutin biasa, alamat yang ada di stack dibaca dan ditulis kembali ke program counter [3].

\section{E. Program memori}

AVR Atmega16 memiliki ruang pengalamatan memory data dan memory program terpisah. Memory data terbagi menjadi 3 bagian, yaitu 32 buah register umum, 64 buah register I/O, dan 512 byte SRAM internal.

Register keperluan umum menempati space data pada alamat terbawah, yaitu $\$ 00$ sampai $\$ 1 \mathrm{~F}$. Sementara itu, register khusus menangani I/O dan kontrol terhadap mikrokontroler menempati 64 alamat berikutnya, yaitu mulai dari \$20 hingga $\$ 5 F$. Register tersebut merupakan register yang khusus digunakan untuk mengatur fungsi terhadap berbagai peripheral mikrokontroler, seperti kontrol register, timer/counter, fungsi-fungsi $I / O$, dan sebagainya. Alamat memory berikutnya digunakan untuk SRAM 512 byte, yaitu pada lokasi \$60 sampai dengan \$25F. konfigurasi memory data ditunjukkan pada gambar dibawah ini.

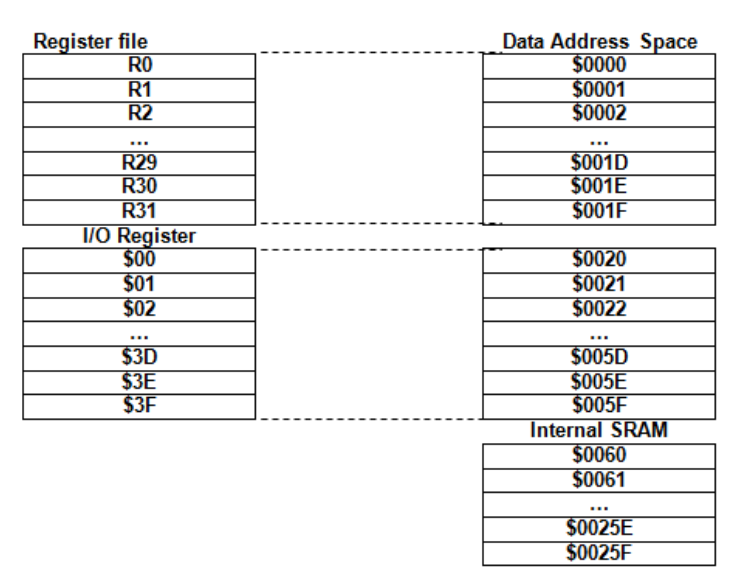

Gambar 3. Konfigurasi Memory data AVR Atmega

Memory program yang terletak dalam Flash PEROM dalam word atau 2 byte karena setiap instruksi memiliki lebar 16-bit atau 32-bit. AVR Atmega16 memiliki 4KbyteXI5-bit Flash PEROM dengan alamat mulai dari $\$ 000$ sampai $\$ F F F$. AVR tersebut memiliki 12-bit programcounter (PC) sehingga mampu mengalamati isi Flash.

\section{F. SRAM Memori}

Atmega16 memiliki 2 Kilo ByteSRAM. Memori ini dipakai untuk menyimpan variabel. Tempat khusus diSRAM yang ditunjuk register SP disebut stack. Stack berfungsi untuk menyimpan nilai yang dipush.

\section{G. EEPROM Data Memori}

Atmega16 memiliki 1024 byte data EEPROM. Data diEEPROM tidak akan hilang walaupun catu daya ke sistem mati. Parameter sistem yang penting disimpan diEEPROM. Saat sistem pertama kali menyala paramater tersebut dibaca dan sistem diinisialisasi sesuai dengan nilai parameter tersebut. 


\section{H. Sistem Interupsi}

Interupsi adalah kondisi yang membuat $C P U$ berhenti dari rutinitas yang sedang dikerjakan (rutin utama) untuk mengerjakan rutin lain (rutin interupsi). AVR Atmega16 memiliki 21 sumber interupsi yang ditunjukkan pada tabel dibawah ini

Tabel 2. Tabel Interupsi

\begin{tabular}{|c|c|c|c|}
\hline $\begin{array}{l}\text { Vector } \\
\text { No }\end{array}$ & $\begin{array}{c}\text { Progr } \\
\text { am } \\
\text { Addre } \\
\text { ss }^{(2)}\end{array}$ & Source & Tuterrupt Definition \\
\hline 1 & $0 \times 000$ & RESET & $\begin{array}{l}\text { Extermal Pin Power-on Reset, Brown-out Reset } \\
\text { and Watchdog Reset }\end{array}$ \\
\hline 2 & $0 \times 001$ & INIO & Extemal IntermtRequest0 \\
\hline 3 & $0 \times 002$ & INII & Extemal IntenmtRequest I \\
\hline 4 & $0 \times 003$ & TIMER CONP & Tiner Comter 2 Compas Natch \\
\hline 5 & $0 \times 004$ & TIMER OVF & Tiner Coumter2 Overtlow \\
\hline 6 & $0 x 005$ & TIMERICAP! & Tiner Comter I Capture Event \\
\hline$?$ & $0 \mathrm{x} 000$ & TIRERICOMA & Tiner Comter Compan Match A \\
\hline 8 & $0 \times 007$ & TIIERICONPB & Tine Comperl Conpas Natch B \\
\hline 9 & $0 \times 008$ & MIERIOVF & Timer Comter Overtiow \\
\hline 10 & $0 \times 009$ & TINEROOVF & Tines Coumiero Overflow \\
\hline$\Pi 1$ & $0 \mathrm{x} 00 \mathrm{~A}$ & SPI,STC & Serial Tranffer Complate \\
\hline 12 & $0 \mathrm{xOOB}$ & USART,RXC & USARI, Rx Conpliste \\
\hline 13 & $0 \mathrm{x} 00 \mathrm{C}$ & USART,UDRE & USARTData Register Ennty \\
\hline 14 & OXOOD & USART, IXC & USART, IX Complete \\
\hline 15 & $0 \mathrm{xOOE}$ & ADC & ADC Conversion Conplate \\
\hline 16 & $0 \mathrm{xOOF}$ & EE RDY & EEPROMReady \\
\hline 17 & $0 \times 010$ & ANACOMP & Analog Comparator \\
\hline 18 & oxo11 & TW1 & Two-wire Serial literfase \\
\hline 19 & $0 \times 012$ & INT2 & Extemal linempt Request2 \\
\hline 20 & $0 \mathrm{x} 013$ & TINERO CONP & Tiner Comtero Compase Natch \\
\hline 21 & $0 \mathrm{x} 014$ & SPI!RDY & Store Program) NempriRady \\
\hline
\end{tabular}

\section{Port I/O}

Inisialisasi Port berfungsi untuk memilih fungsi port sebagai input atau sebagai output. Pada konfigurasi port sebagai output dapat dipilih pada saat awal setelah reset kondisi port berlogika 1 atau 0 , sedangkan pada konfigurasi port sebagai input terdapat dua pilihan yaitu kondisi pin input toggle state atau pull-up, maka sebaiknya dipilih pull up untuk memberi default pada input selalu berlogika 1. setiap port berjumlah 8 bit, konfigurasi dari port dapat diatur sesuai dengan kebutuhan. Pengaturan konfigurasi dapat dilakukan perbit, jadi dalam satu port dapat difungsikan sebagai input dan output dengan nilai defaultnya berbeda-beda, menunjukkan setting konfigurasi pada port a dengan kombinasi input dan output yang berbeda-beda.
Perintah dasar sistem input dan output adalah sebagai berikut [6] :

a. Output

PORTX = data;

Yaitu untuk mengirimkan data secara byte ke port X (X = A, B, C, D). perintah out dalam bahasa assembly.

b. Input

data_in $=$ PINX;

Yaitu untuk mengambil data byte dari PINX ( $\mathrm{X}=\mathrm{A}, \mathrm{B}, \mathrm{C}, \mathrm{D})$ yang kemudian disimpan dalam variabel data_in. Perintah ini sama dengan in dalam bahasa assembly.

Sebelum memulai pemograman dasar input dan output dengan bahasa C perlu diketahui bahwa mikrokontroler perlu disetting DDR dan PORT agar digunakan sebagaimana mestinya.

Tabel 3. Tabel Input dan Output

\begin{tabular}{|l|l|l|}
\hline & DDR bit $=1$ & DDR bit $=0$ \\
\hline PORT bit $=1$ & Output $;$ High & Input ; R pull-up \\
\hline PORT bit $=0$ & Output $;$ Low & Input ; Floating \\
\hline
\end{tabular}

Misalnya :

PORTA=0xCC;
DDRA=0x०F;
Dari DDR terlihat bahwa
port A0-3 sebagai output dan
port A4-7 sebagai input,
sedangkan dari port terlihat
bahwa PA0-1 = Low, PA2-3 =
High, PA4-5 sebagai Rpull-up
(floating) dan PA6-7 dengan
Rpull-up.

J. Clear Timer on Compare Match (CTC)

CTC adalah salah satu mode Timer/Counter1, selain itu ada Normal mode, Fast PWM mode, Phase Correct PWM mode. Pada CTC mode maka nilai TCNT1 menjadi nol jika nilai TCNT1 telah sama dengan OCR1A atau ICR1. Jika nilai top ditentukan OCR1A dan interupsi diaktifkan untuk Compare Match A maka saat nilai TCNT1 sama dengan nilai OCR1A interupsi terjadi. CPU 
melayani interupsi ini dan nilai TCNT1 menjadi nol.

\section{K. USART}

Selain untuk general $I / O$, pin $P D 1$ dan $P D O$ ATMEGA32 berfungsi untuk mengirim dan menerima bit secara serial. Pengubahan fungsi ini dibuat dengan mengubah nilai beberapa register serial. Untuk menekankan fungsi ini, pin PD1 disebut TxD dan pin PD0 disebut RxD. Nilai UBRR dan clock sistem menentukan laju bit pengirim dan penerima serial.

\section{METODE PENELITIAN}

\section{A. Teknik Pengumpulan Data}

Dalam mengumpulkan data, teknik pengumpulan data yang digunakan dalam penelitian ini yaitu: Pustaka, Obsevasi, Wawancara Dan Dokumentasi.

\section{B. Metode Pengembangan Sistem}

Metode yang digunakan untuk pengembangan sistem dalam penelitian ini adalah model proses Prototype. Model prototype (Prototyping model) merupakan suatu teknik atau proses untuk mengumpulkan informasi tertentu kemudian membangun sebuah model dari sebuah sistem berdasarkan pada kebutuhan pengguna, dengan kondisi pengguna tidak memberikan detail input, proses, dan output, dalam situasi seperti ini maupun situasi lain, paradigma prototyping bisa memberikan pendekatan terbaik, Model tersebut dapat berupa tiga bentuk:

1. Bentuk prototype di atas kertas atau model berbasis komputer yang menggambarkan interaksi manusia yang mungkin terjadi.

2. Working prototype, yang mengimplementasikan sebagian dari fungsi yang ditawarkan perangkat lunak.
3. Program jadi yang melakukan sebagian atau seluruh fungsi yang akan dilakukan, tapi masih ada fitur yang masih dikembangkan

\section{Prinsip Kerja Sistem}

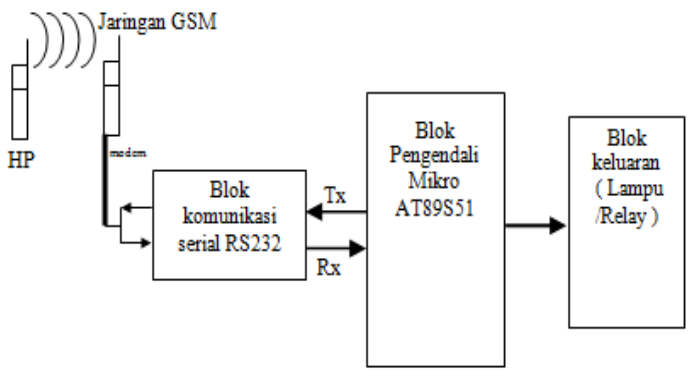

Gambar 4. Bagan Kotak Prinsip Kerja Sistem

D. Flowchart Perancangan Prangkat Lunak

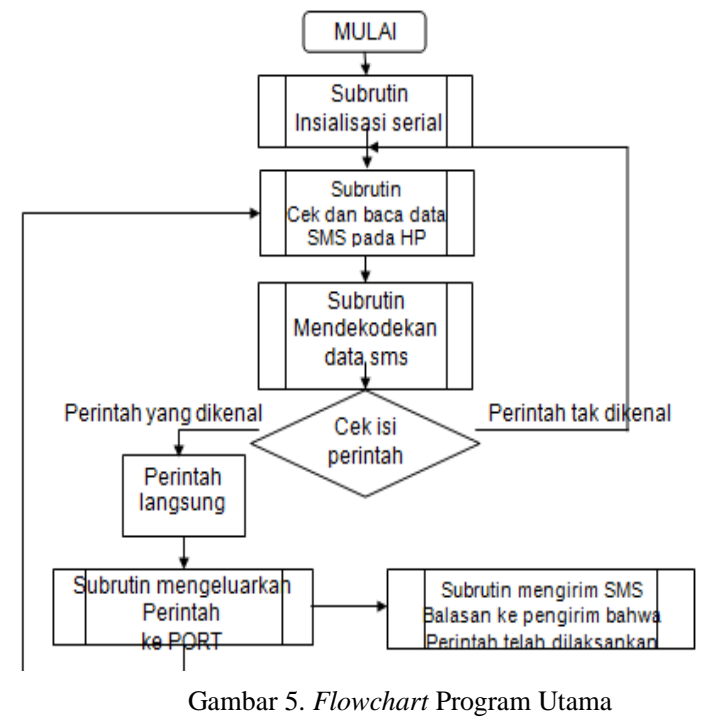

\section{HASIL DAN PEMBAHASAN}

\section{A. Hasil}

Implementasi Aplikasi Remote Kontrol CPU/Laptop Jarak Jauh Dengan Media Serial Handphone Dengan Mikrokontroler merupakan pengembangan sistem. Salah satu aspek pengembangan sistem aplikasi ini adalah aspek pengendalian dan kecepatan proses terkait dengan prosesor yang digunakan.

Mikrokontroler Atmega16 sebuah rangkaian digital pada satu sirkuit terpadu yang berisi inti prosesor, memory dan Input/Output. Memori 
program dalam bentuk flash atau ROM juga sering disertakan pada chip, serta jumlah yang kecil RAM.

Mikrokontrolermerupakan sinyal campuran yang mengintegrasikan komponen analog yang diperlukan untuk sistem kontrol elektronik nondigital. Sedangkan prinsip kerja sebuah mikrokontroler dapat dijelaskan sebagai berikut :

1. Berdasarkan data yang ada pada register program counter. Mikrokontroler mengambil data dari ROM dengan alamat sebagaimana ditunjukkan dalam program counter. Selanjutnya program counter ditambah nilainya dengan 1 secara otomatis. Data yang diambil tersebut merupakan urutan instruksi program pengendali mikrokontroler yang sebelumnya telah dituliskan oleh programmer.

2. Instruksi diolah dan dijalankan. Proses pengerjaan bergantung pada jenis instruksi, bisa membaca, mengubah nilai-nilai dalam register, $R A M$, isi port atau melakukan pembacaan dan dilanjutkan dengan pengubahan data.

3. Program counter telah berubah. Selanjutnya yang dilakukan mikrokontroler adalah mengulang kembali siklus ini pada langkah program counter dengan nilai 1.

4.

Kemudian dalam melakukan uji analisis sistem yang dipakai adalah CodeVisionAVR C 2.05.3 dan Microsoft Visual Studio 2008. Sebelum menggunakan CVAVR sekaligus sebagai downloader, lakukan setting sebagai berikut :

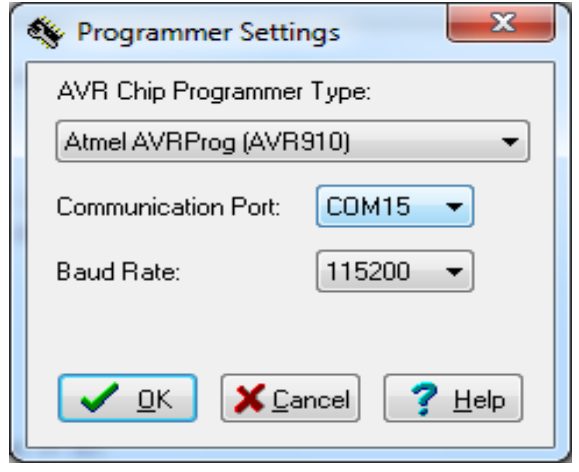

Gambar 6. Programmer Setting

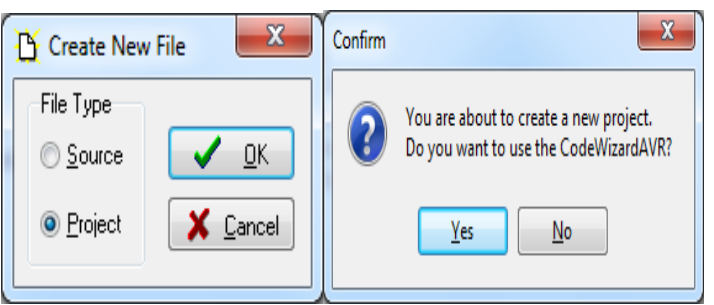

Gambar 7. Pembuatan New Project

Maka akan muncul tampilan CodeWizardProject, kemudian sesuaikan bagian yang diinginkan.

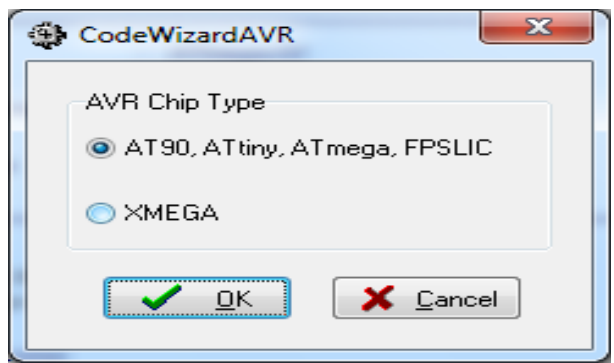

Gambar 8. Konfirmasi Code WizardAVR

Atur bagian chip, pilih Atmega16 dan clock 8.000000 terlihat pada Gambar 9 .

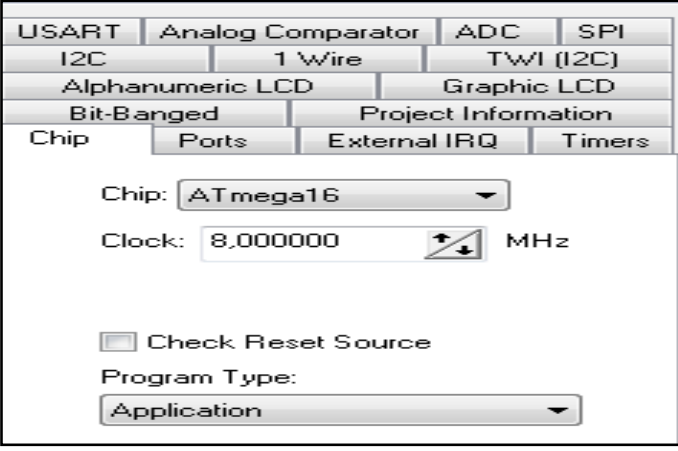

Gambar 9. Bagian Tab Chip

Atur bagian USART, beri checklist pada receiver, $r x$ interupt, dan transmitter. Terlihat pada Gambar 10 
Jurnal Pseudocode, Volume III Nomor 1, Februari 2016, ISSN 2355 - 5920

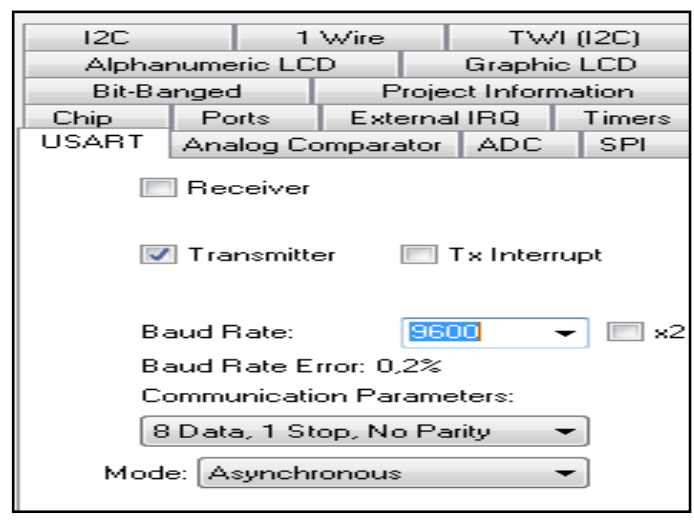

Gambar 10. Bagian Tab USART

\section{B. Pembahasaan}

Dari skenario yang dibuat, diperoleh hasil pengujian sistem Aplikasi Remot Kontrol CPU/Laptop yaitu bluetooth adalah media perantara nirkabel. Data yang dikirim melalui dalam bentuk serial asinkron. Aplikasi terhubung dengan bluetooth secara serial asinkron. Handphone mengirim data secara serial, yang kemudian diteruskan ke bluetooth yang terhubung dengan mikrokontroleratmega16. aplikasi menerima data serial dari bluetooth melalui cara interupsi serial. Adapun tabel hasil pengujian Aplikasi Remote Kontrol CPU/Laptop sebagai berikut :

Tabel 4. Hasil Pengujian

\begin{tabular}{|l|l|c|c|c|c|}
\hline No & Perintah & $\begin{array}{c}\text { Kode } \\
\text { ASCII }\end{array}$ & $\begin{array}{c}\text { Jarak } \\
\text { Bluetooth }\end{array}$ & $\begin{array}{c}\text { Jumlah } \\
\text { Percobaan }\end{array}$ & $\begin{array}{c}\text { Persentasi } \\
\text { Keberhasilan }\end{array}$ \\
\hline 1 & restart & $/ r$ & 10 Meter & 10 & $100 \%$ \\
\hline 2 & Shutdown & $/ s$ & 10 Meter & 10 & $100 \%$ \\
\hline
\end{tabular}

Tabel 5. Hasil Pengujian Rintangan

\begin{tabular}{|c|c|c|}
\hline No & $\begin{array}{l}\text { Kode } \\
\text { ASCII }\end{array}$ & Keterangan \\
\hline 1 & آ & $\begin{array}{l}\text { Tampilan antar muka harus menjadi pilihan pertama, } \\
\text { tidak menggunakan opsi lain. }\end{array}$ \\
\hline 2 & $\pi$ & $\begin{array}{l}\text { Log Off, tidak dapat digunakan dengan pilihan /m } \\
\text { atau /d berdasarkan Id Windows }\end{array}$ \\
\hline 3 & 19 & $\begin{array}{l}\text { Shutdown dan restart komputer. Setelah sistem } \\
\text { reboot, restart jika aplikasi terdaftar. }\end{array}$ \\
\hline 4 & /a & $\begin{array}{l}\text { Hal ini hanya dapat digunakan selama periode time- } \\
\text { out. }\end{array}$ \\
\hline 5 & $1 / p$ & $\begin{array}{l}\text { Matikan komputer lokal tanpa batas waktu atau } \\
\text { warning. Jika digunakan dengan / d dan / opsi f. } \\
\text { berdasarkan Id Windows }\end{array}$ \\
\hline 6 & Th & $\begin{array}{l}\text { Hibernate komputer lokal. Dapat digunakan dengan I } \\
\text { f opsi berdasarkan Id Windows }\end{array}$ \\
\hline 7 & /e & Dokumen untuk shutdown dari sebuah komputer. \\
\hline
\end{tabular}

Tabel 6 Hasil Pengujian Bluetooth

\begin{tabular}{|c|c|c|c|}
\hline No & Jarak Bluetooth & Kendala Yang dihadapi & Keterangan \\
\hline 1 & 1 Meter & Tidak Ada & Sesuai Yang diingikan \\
\hline 2 & 2 Meter & Tidak Ada & Sesuai Yang diingikan \\
\hline 3 & 3 Meter & Tidak Ada & Sesuai Yang diingikan \\
\hline 4 & 4 Meter & Tidak Ada & Sesuai Yang diingikan \\
\hline 5 & 5 Meter & Tidak Ada & Sesuai Yang diingikan \\
\hline 6 & 6 Meter & Tidak Ada & Sesuai Yang diingikan \\
\hline 7 & 7 Meter & Tidak Ada & SesuaiYang diingikan \\
\hline 8 & 10 Meter & Tidak Ada & SesuaiYang diingikan \\
\hline 9 & 15 Meter & Koneksi Bluetooth Gagal & Tidak Sesuai \\
\hline 10 & 20 Meter & Koneksi Bluetooth Gagal & Tidak Sesuai \\
\hline
\end{tabular}

Tabel 7 Hasil Pengujian Rintangan

\begin{tabular}{|c|c|l|c|}
\hline No & Jarak Bluetooth & Kendala Yang dihadapi & Keterangan \\
\hline 1 & 1 Meter & Tembok Kaca & Sesuai Yang diingikan \\
\hline 2 & 3 Meter & $\begin{array}{l}\text { Tembok Kaca dan } \\
\text { Tembok Semen }\end{array}$ & Sesuai Yang diingikan \\
\hline 3 & 4 Meter & $\begin{array}{l}\text { Tembok Kaca dan 2 } \\
\text { Tembok Semen }\end{array}$ & SesuaiYang diingikan \\
\hline 4 & 6 Meter & $\begin{array}{l}\text { Tembok Kaca dan 3 } \\
\text { Tembok Semen }\end{array}$ & Sesuai Yang diingikan \\
\hline
\end{tabular}

\section{KESIMPULAN DAN SARAN}

A. Kesimpulan

Ada beberapa kesimpulan yang dapat diambil dari hasil pengujian sistem, yaitu :

1. Dalam melakukan pengujian, aplikasi memiliki batas jarak 10 Meter, jika lebih dari 10 Meter koneksi bluetooth gagal, karena sifat bluetooth memancarkan frekuensi, sehingga tidak ada halangan, kecuali hanya jarak jangkauan pada bluetooth.

2. Aplikasi yang digunakan harus handphone berbasis Android, dikarenakan ada software tambahan yaitu bluterm.

3. Dalam melakukan kriteria pengujian aplikasi kontrol jarak jauh menggunakan aplikasi Code Vision AVR, kelebihan tools pada code wizard dalam pengembangan sistem bisa lebih kompleks, tampilan editor Code Vision $A V R$ lebih mudah dipahami oleh pemakai namun terkendala pada licensed software yang cukup mahal. 
B. Saran

Peneliti menyadari masih banyak kekurangan oleh karena itu berdasarkan masalah yang ditemukan dalam penelitian, diharapkan implementasi aplikasi kontrol jarak jauh bisa menggunakan sms gateway sehingga aplikasi dapat menggunakanhandphone apa saja dan aplikasi kontrol jarak jauh menggunakan mikrokontroller Atmega32 dapat dikembangan lebih komplek lagi.

\section{REFERENSI}

[1] Immanuel, Alpha, 2010, Pembuatan Aplikasi Pengontrol Robot Berbasis Android.

[2] Sumardi, 2013, Mikrokontroler Belajar AVR Mulai Dari Nol, Graha Ilmu. Yogyakarta.

[3] Syahid, 2012, Rancang Bangun Robot yang Memiliki Lima Drajat Kebebasan, jurnal Ilmiah Foristel Vol. 1, No 1,Maret 2011.Aplikasi Pengontrol Robot Berbasis Android". 